\title{
Letters from the future: an exercise with child welfare predictions
}

\author{
Tarja Pösö
}

\begin{abstract}
The article presents an empirical exercise about predictions in child welfare. In the exercise, social workers imagined letters which they could receive from a child and his/her parents in five years' time. The children had been in care for one year at the moment of letter-writing. When the social workers wrote the imaginary letters, they used their professional imagination, based on practice knowledge and experience, and were involved in a role-play.
\end{abstract}

The analysis of the letters (34 from 'children' and 33 letters from 'parents') demonstrates four themes shared by the letters: ordinary life, family contacts and return home, social problems as shadows and assessment of the placement. Two narratives were performed: the narrative of future of ordinary life and that of the troubles. It is suggested that imaginary letters are helpful in highlighting practitioners' sense of the future, professional imagination as well as the empowering and critical points in practice.

Keywords:

child welfare, professional practice, anticipation, future, role-plays, narratives as performances

Acknowledgement: This work was supported by the Academy of Finland under Grant [264124].

\section{Introduction}

Assessments, investigations and care plans belong to the repertoire of child welfare. They build strongly on the past and present, but also include, more or less explicitly, views about the future ahead. Indeed, the anticipation of the future is embedded in many ways in child welfare. A good example is how in Finland decisions to take a child into care are regulated: several criteria should be met, one of them being that, according to the Finnish Child Welfare Act, a care order decision should be made only if the future substitute care is in the best interest of the child (Pösö and Huhtanen 2017). In line with this criterion, the social worker should anticipate the future and its 
impact on the child's well-being and give convincing arguments as to why the child should or should not be taken into care. Although knowledge and experience may guide that anticipation, it is in its essence a prediction about the likely future. This is to say that even the statutory decisions of child welfare rest to some extent on predictions of the future.

In addition, anticipation of the future is an inevitable element in certain professional approaches such as solution-focused, strength-based and constructive social work (e.g. Saleeby 1997; Ungar 2004; Parton 2012; Seikkula et al. 2003). Their view is that the way we see the future has an impact on how we view our identity, present social situation and the changes needed. The temporality of the future should therefore be actively explored, narrated and imagined in those case work approaches. Furthermore, imagining and anticipating the future is important not only in case work but also on the level of the systems. On this level, imagining the future can guide the ways in which the weaknesses of the present system can be changed (Adams et al. 2005; Featherstone et al. 2014). Overall, views on the future matter in social work, and consequently narratives about the future provide a rich yet complex platform for social work research (Larsson and Sjöblom 2010).

The exploration and rationalisation of future probabilities is the preserve of decisionmaking studies in particular (e.g. Munro 2008; Taylor 2009; Shlonsky and Benbenishty 2014). These studies also point out the uncertainty of predictions, and that social workers' predictions can rarely be based only on the 'facts' of the case at hand (Taylor and White 2006; Swift \& Callahan 2009; Trevithick 2014; Banks 2016). 'Gut-feeling', intuition, tacit knowledge and practice wisdom - the contested but yet essential elements of social work and any human service work - play an important part in social work narrations of the future and need to be considered as well (e.g. Fahlgren 2009; Barfoed and Jacobsson 2012; Samson 2015). They do, however, challenge the methodology of research.

In this article, we study social workers' narrations of the future of their clients by employing letter writing as a method. A group of social workers working with children in out-of-home care in Finnish child welfare was asked to imagine the future of their clients five years ahead. They imagined a letter which the child and his/her 
parent would write to the caseworker. The social workers found this exercise empowering and fair to their professional experience with the result we decided to explore the letters and letter writing in detail in this article. The contents of the letters as well as the nature of the predictions as narrative performances will be analysed in the empirical section of this article. However, we start our exploration with a section on letter writing in social work research.

\section{Writing letters}

The search for new methods to make the silent, sometimes excluded 'voices' of either service-users or practitioners heard has been going on for a while in social work research (e.g. Witkin and Chambon 2007: Hardwick et al. 2016). The concern has been - and still is - that some existing methods restrict and bind, instead of enabling, those voices to be heard. Creative methods and practice-research have expanded the methods used in social work and as a result, they have included a wider array of themes and voices in the agenda of research methods (e.g. Bryant 2015). In particular, they have strengthened the 'insider views' of service-users and practitioners (e.g. Smith 2009; Hall 2012). Nevertheless, at the same time, it has been argued that new methods are not necessarily needed, but that rather we should use the existing methods creatively (Harwick et al. 2016). Letters provide a good example: although letters have been used in research for a long time, new approaches to writing and reading letters have only recently been introduced by feminist studies in particular (e.g. Livholts 2014).

However, in social work research, letters - unlike poems - have not gained a firm foothold among the creative methods (e.g. Deacon 2006; Bryant 2015). This is surprising, as it is known that letter writing has also been a tool for social work practice. In the early years of the $20^{\text {th }}$ century for example, the reform schools taught their residents how to write letters to their parents at home. When doing this, the residents were instructed how to narrate their lives (Vehkalahti 2009). Rather more attention in social work has been given to the letters which social workers write as part of their institutional work. They write letters to invite service-users to a meeting or to ask for an expert assessment. Then the very question of writing style becomes an 
important issue for which guidelines are given in textbooks for practitioners (e.g. Healy and Mulholland 2010).

Unlike the use of letters described above, letters are used here as a platform for imagination; yet not for any type of imagination (e.g. sociological imagination as suggested by Mills 2000) but specifically for professional imagination. Professional imagination, as understood here, is embedded in practitioners' experiences and knowledge of practice. Although imagination is typically linked more with art and other creative work than with professional social work, yet, as Chamberlayne and Smith (2007) argue, both social work and art often work at the borders of the sayable, the thinkable and the knowable. Imagination may link the sayable and knowable with those experiences which have so far escaped words.

In this article, professional imagination is directed towards the future as our interest is in predictions, and, as social work practice is, by its very nature, based on interactions, we study professional imagination here as a dialogical exercise (e.g. Seikkula et al. 2003). Social workers are asked to take the role of their client and write a letter from the future in their position. Such role-plays, resting on the idea of constructing a realistic situation of social work through imagination, belong to the methods of social work (Hepworth and Larsen 1993) and social work education (e.g. Hargreaves and Hadlow 1997; Askeland 2003). We follow this tradition when we asked the social workers to imagine the letter written by the child and his/her parents in five years' time.

Data and method

In 2013, 37 children were taken into care in two Finnish municipalities during a period of six and eight months for the bigger and smaller municipalities respectively. The social workers who were the children's caseworkers were involved in a study examining the 'black box of the care' of those children (Pösö et al. 2015; Pösö et al. 2016). They completed two questionnaires: the first six months after the care order had been introduced, and the second one six months later. Both questionnaires included questions about the child's time in care and the services provided. The forms 
were an outcome of a series of workshops between the social workers and the researchers in which the relevant questions were first discussed before the results were later analysed together. The workshops numbered 13 and included 17 social workers and three researchers over a period of two years.

The second questionnaire included two future-orientated questions at the end of the survey questions of 45 and 46. Question 45 was: "Imagine the situation that you receive a letter sent by this child five years from now. The child would write about his/her life. What would be written in the letter?", while question 46 was: "Imagine the situation that you receive a letter from the biological parent(s) of this child five years ahead. In that letter, the parent(s) tell about their life. What would be written in that letter?" These questions included an invitation to imagine the letters. This idea emerged in the workshops as a way to explore the practitioners' anticipation of the children's future. No other method seemed to provide us the opportunity to include the 'gut-feeling' of the practitioners in the future predictions of their clients. All parties agreed that it was worth testing this method.

The task resulted in 67 letters being written: 34 'from children' and 33 'from parents'. Some were just a couple of sentences whereas others made a story of half a page. Some letters were 'authored' by the child ('I attended the concert of my favourite band recently ...') whereas others were written in a more passive way ('The child would write about ...'). The contents and the details of the imaginary letters surprised us. When we expressed our surprise to the social workers in the workshops, they answered that it was a very pleasant and empowering task to do. They often receive letters from children and it was easy to imagine what the letters would be like. They also enjoyed the free and indirect form of expressing their professional understanding of the child's future. The other questions in the questionnaire had channelled their professional knowledge into certain answer categories whereas the letter allowed them to narrate more freely and was thus welcomed. This is a reminder of the nature of social work knowledge being "narrative, holistic and discursive knowledge” (e.g. Parton, 2008; Bradt et al. 2011).

Despite this freedom for expression, the letters reflect the institutional relation between the social worker, child and his/her parents. This is noticeable in how the 
letters are narrated: they state clearly whether the child, the imaginary author of the letter, is in care or not. All the under-aged children are described as still being in care in five years' time apart one child whose care order would be terminated. Otherwise those children who wrote their letters outside the care system had aged out of care.

The imaginary letters from parents differ from those from children. The social workers write in five cases that the parent would not write a letter because of his/her early death, alcoholism or lack of knowledge of the Finnish language; some other parents would remain so distant from their child's life that they would not write. Some letters include sections from a father and mother separately, emphasising their conflicting views and positions in relation to child welfare and the child. The tones of the letters are much more critical towards the child welfare system than those of the children.

The analysis of these letters, which are so different in terms in style and length, is first based on (naturalistic) thematic coding of the future descriptions. In total, four thematic categories - ordinary life, family contact and returning home, social problems as shadows and the role of the placement - cover the common themes of the letters. They will be presented below before a shift in the analytic stance takes us to an interpretation of the descriptions of the future as narrative performances (Gubrium and Holstein 2009). This rests on the view that letters provide a platform for storytelling and that storytelling is staged: stories are designed for listeners and for a particular effect (ibid, 81). When writing, one assumes a reader for the text as writing is an interactive practice (e.g. Hearn 2012); in our exercise the social workers assumed the researchers to be the readers. The narrative performances are thus dialogical (Riessman 2008, 105-140): when 'imagining' the letters with a research reader in mind, the social workers made certain issues of child welfare visible. 
Letters from the future: the main themes

\section{Ordinary life}

The letters by children were rich in descriptions of school days, school achievements, friends, types of games, pets, holiday activities and hobbies. We call them 'ordinary childhood issues'. The following extracts demonstrate an ordinary childhood.

I have two new friends as two new boys moved to stay with us. We play with them and spend time outdoors. Tiina's dog died last week, it was very sad. We all attended the funeral. I threw some sand into the hole.

Now when I'm finishing the sixth class I feel a bit nervous about the start of secondary school. I do learn to know new people quickly so I will certainly get new friends. I can concentrate now better on my school tasks, although sometimes I feel bored and would like to do something nice. I have good friends close to home and more in the riding club. I really like the horses. It would be nice if I could go riding more often.

Hi, I just attended the concert of my favourite band with my foster parents and siblings. Nice it was. School goes well.

In the first extract, the child has been imagined to say that "two new boys moved to stay with us" which is written in such a way that there is reason to believe that the boys have been placed into care in the same home as the child. In the third extract, it is explicitly written that the child attended the concert with her foster parents and siblings. Although the children are still in care in five years' time, the key message is that the children are actively and happily enjoying ordinary events in childhood.

Those children who had aged out of care wrote about education, jobs, dating and family relations - issues that young adults typically deal with. The following letter includes a rich mixture of such issues and is written in a very cheerful and optimistic style. 
Hi! Do you still remember me? You were my social worker a long time ago. You must have heard about me from the after-care worker but I now want to tell myself. I have finished my studies as a practical nurse and got an internship in a kindergarten! It has been awesome. You might remember that I like children. I live with my boyfriend. My dad and brother often visit us, sometimes they help. Mum, well, I sometimes visit my mum. Mum does not like my boyfriend and we often quarrel about it but I have thought to keep myself calm and not become too involved. I must have been very troublesome sometimes, and even you did not always understand me. It was just so difficult for me then. I am however so glad that you eventually found me a good placement. I still keep in touch with them and I got good friends. Also, my mum and dad liked it. And I finished school! I always remember how you once picked me up from school. We spoke during the car journey and you told me how good I am at baking and you can't do it. I could still teach you if you wish. Call me if you want to. My contact info is here. Wishes Anna (name changed)

The letter includes memories of joint moments between the child and the social worker: it says that the social worker, that is the reader of this letter, had an institutional role (the beginning of the letter) but that the relations were informal as well (about baking at the end of the letter). The placement in the foster home and the social worker's role are mentioned in a positive light. There is also an invitation for a future personal contact: the young adult could come and instruct the social worker how to bake.

Imaginary letters from the parents also contain descriptions of life, as any descriptions of adults would do: jobs, new relationships, housing and their role as parents. The following extract describes a mother's letter in which motherhood and children play an important role. The letter focuses on the child to be born and on an appraisal of the author's motherhood.

I'm just about to move into a new flat. Things are going well for me, I'm pregnant and expecting a new baby which the children have wished to have. 
I'm dating with a new male friend who also likes children and who thinks I'm a good mother.

\section{Family contact and returning home}

The letters from children in care systematically include reports about family contact: how often the child meets his/her parents and other close ones, where the meetings take place and how the child feels about the contacts.

I will go home again at the weekend, my granny and also my sister will visit us. My brother goes now to vocational school and visits home as well, always when I'm there. In the summer, we will travel with the caravan with my father and mother.

The best is the summer holidays. I can visit both grannies and when at my granny’s in Helsinki I could go and see my mum and my dad at my granny's in Tampere. Mum and granny do not speak so badly about my dad and they do not say anymore that I should leave my foster home to live with them.

$\mathrm{Hi}$, thank you that I can meet father in his home and that I can play there together with my siblings.

The first letter describes the holiday plans with the child's parents as well as the ordinary weekend visits at the parents' home, bringing together her grandmother and siblings. Holiday plans are also presented in the second extract. The visit at the grandmother's allows the child to meet both parents and there is some optimism about smoother relationships among the family members. In the third letter the author thanks the social worker for organising the contact with the father. The messages about family contact are twofold: there is the gratefulness expressed by the child but also the recognition of the institutional role of the social worker as the child's family 
contacts are regulated by the social worker. The wishes of returning home are expressed in small words as demonstrated here

I like it here but I would like to go home already.

I think that things have made progress and I could already now move to live with my father.

Differently from the children's letters, the imaginary letters from parents more rarely address visits at home and summer holiday plans. Instead the issue of terminating the care is a common theme in addressing family contacts and home returns. In the letter below, the author - the mother - writes about her wish to have the children with her. The mother is contesting the care order and blames the father of the children for the difficulties.

I've said that the care order was due to the children's father, it was not my fault. I wonder why you don't see me as a good mother as the others do. I'd like to have the children with me. The father of the children cannot ever have the children to stay with him, I'll see to that.

\section{Social problems as shadows}

Some letters report major troubles in life and difficulties in finding a satisfactory place in society. In particular, the difficulties in finding a job are commonly mentioned in the letters by children who have aged out of care. In the first letter below, the lack of a permanent full-time job overshadows the life of the young person. Health issues are mentioned as well but are somehow manageable. The second letter gives only hints of likely troubles, social withdrawal and the need for family support because of parenting issues.

Hi, how are you? I have mixed issues. I managed to get an occupation but I have not got any permanent job. I've had some trial periods but they've always been interrupted. Now I work part-time. I have to remember to take my medicine; if not, I'll become sick. I sometimes 
visit my foster home. I spend time with my brother and I have a couple of friends. I speak from time to time about the old things with my mother. I’ve tried therapy but didn’t finish it.

The youngster would say that she has moved several times after the placement. The youngster has had several relationships and now she has a child who's two years old. The family worker visits the family. The youngster tells that she experiences her placement as having been difficult but also that she somehow profited from it. She keeps in touch with her parents only very little. She finds it difficult to form social relations. She has only completed compulsory education and has had periods in supported employment.

Sometimes even financial problems, linked to unemployment, can be written about in a positive way if there is something to balance them. In the following extract, a girl writes about the shadow of poverty, but also about the delight at her pregnancy.

I’m now living with my boyfriend, and neither of us works. It isn't easy nowadays to find job. We live on income support and I'm two months pregnant. This baby is really wished for!

Some letters take it for granted that the child would be socially excluded in five years' time. This is demonstrated by the following texts:

The young person will not send a letter to me. If no change takes place, the youngster will be in prison in five years.

In five years' time, the youngster will be socially excluded (no occupational training, no employment, lives with his mother and siblings).

Social exclusion is also a common reason explaining why the parents would not write any letters as described in the method section. Alcoholism, mental health issues and imprisonment are the main descriptions of parents' social problems. 
The role of the placement

The letters from young adults include assessments of the quality of the placement. Most letters report gratitude and satisfaction.

I've been very pleased with the foster home and got a lot of help there. Now I meet my parents and friends more often, although the job takes a lot of my time. Life goes very well. Greetings to you and all the best to you!

All in all, the placement was a good thing and the relations with my mother improved.

The children's home was not so bad after all. I've visited it several times afterwards and called my key worker there.

A different tone is expressed in the letter below in which the bitter experiences of maltreatment in the residential institution are mentioned. The remark is mixed: the child welfare system had offered some help but at the same time abused her/him.

He writes that he got some help from child welfare but the letter includes bitter experiences about the residential institution in which he was badly treated. This young adult hopes that he would have got more tools to control his emotions.

Equally the letters from parents include assessments and feedback about the placement. They typically express either deep gratitude or strong doubts about the placements. The first extract by a parent is written in a positive tone about her/his children's time in care whereas the second one includes strong criticism of the care order decision as such but is more positive about the placement.

The boy visits home at the weekends and things seem to be alright for him. The other boy stopped wetting the bed finally. It was tough. Secondary school was tough and there was some bullying, but fortunately the foster home dealt 
with it well. What else could there be? Well in the summer we'll go off with our caravan.

The child's mother would write about the period before the care order and about the false reasons for the care order and that the parents were unfairly treated and that their words were wrongly used. Despite her criticism, the mother is of the opinion that it is best for the child to live in the foster home which the child is used to and which has all her friends close by.

Sometimes, albeit infrequently, the letters from parents include questions to the social worker. The questions may be about their rights as service-users. The style of writing is similar to asking for consultation. What to do with my child?

Hi! We have had some problems with our after-care worker about the payment of grants for independence. Could you find out more? (This would be a letter from a mother, the father would not possibly take the initiative and write a letter).

Hi! I'm writing about a troublesome topic. My daughter receives after care services, you must know it, and things are not working out at all well. I have tried several times to tell the after-care worker that the boyfriend is not good company for my daughter but s/he does not seem to understand it. The father does not do anything as always. You must remember his style, he has always neglected his responsibilities. I am very disappointed with the situation. I now would like to ask what the duties and regulations of aftercare are. I have been planning to contact a lawyer. This is of course ahead of us as so many child welfare referrals without any reason have been made about our son. I do not understand the way how the school functions. The child has his diagnoses; I can't do anything about them. Why do they make child welfare referrals about a child who will never become normal?

Those letters, which include requests for advice and consultation, remark upon a specific type of relationship with the parents and social workers: they together take 
care of the child. A relationship of this kind could continue even after the formal position in the system had ended as hinted at by the letters.

'Future' as a narrative performance

The following section looks at the key narratives of the future constituted by the themes in the previous section. We cross-read the themes and looked at the overarching thematic narratives that run through them. The theme of ordinary life forms a narrative on its own. We call this 'the narrative of the future of ordinary life'. This narrative is notably the core of the anticipated future. In addition to this narrative, the topic of troubles in the future runs through the themes. It is at its strongest in the theme about social problems as shadows but the existence or likelihood of troubles is evident in other themes as well. We call this 'narrative the future of troubles'.

Within the narrative of the future of ordinary life, everyday-life, school, employment, family relations, friends and pets are the topics widely written about, and the smooth running of every-day life sets the main frame for the future. Consequently, the children and parents are positioned as anyone else growing up and moving on with his/her life. Social workers are persons who are familiar with, and interested in, their (ordinary) lives. Shared memories and experiences mark the future, and the contact between the social worker, child and parents is solid. The emotional landscape of the narrative is coloured by gratitude and satisfaction and only occasionally by touches of bitterness. The letters are authored so that the positive elements of client-social worker relationships become evident and that even the very authoritative tasks of social work are seen in the light of the child's (or the family's) best interests. Indeed, the human element of the relationship between the imagined author and reader was emphasised, highlighting the 'human factor' in child welfare (Featherstone et al. 2014).

This narrative includes a statement about the impact of the care order: 'ordinary life' is an outcome of the care order. When social workers describe ordinary life in the imaginary letters, they also describe the good and intended consequences of their 
work with the emphasis on social inclusion in 'ordinary life'. The description of a child having a good time in school, as we have seen above, may be an outcome of the input of a social worker who has managed to find enough educational support for a child who has possibly failed her/his earlier studies and has lacked motivation.

Likewise, weekly riding sessions may have required some therapeutic support for the child to overcome his/her shyness and social withdrawal, as well as financial contributions provided by the child welfare system. These are examples which the social workers shared with the researchers in the workshops. According to a study by Helavirta (2016), social work with children in care in Finland includes a lot of organising of supportive services and resources for the child, the aim of which is for the child to have an 'ordinary life'.

The narrative of the future of troubles describes the future as being overshadowed by social problems and even social exclusion or their likelihood. It may be children or their parents or both who live troubled lives. These predictions about the future five years ahead include an assumption that the present situation will not have changed or actually it will have become worse. The letters give a hint of the continuation of very problem-loaded situations and conflicts with the child welfare agency and social workers and that the social workers cannot do anything to change the problems or conflicts. For children, ageing out of care may mean a likelihood of troubled early adulthood.

A lack of contact is typical for this narrative of the future. This is especially the case with the parents who have withdrawn from contact due to their personal problems or conflicts with the child welfare system. Their contacts with the children and young people are distant and formal but this is mainly only when they have left care. This is very different from the narrative of the future of ordinary life in which the positive contacts during the placement play an important role.

In sum, the narratives perform the future as including both social inclusion and exclusion of children and parents as well as solid, distant or non-existent relationships between social workers, children and families. The narrative of the future of ordinary life contests the public image of child welfare as focusing only on problems and regulation (e.g. Warren 2016) and instead describes the future as being rich in 
relationships and every-day life. Obviously, the social workers used the opportunity to write the imaginary letters from their clients so that the positive elements and outcomes of child welfare became visible. The narrative of the future of troubles, on the other hand, performs the future as escaping the good intentions of child welfare, and thus informs about failures. The anticipation of a troubled future takes it for granted that some life-courses and relationships will be problem-loaded. When writing the letters from the future, the social workers performed a future scenario which is beyond their impact. In that scenario, social workers have very little contact with the children and parents; yet, the troubled future is mainly after the placement. As long as children are in care, their future is imagined to be less troubled and more inclined towards 'ordinary life'.

\section{Conclusions}

In the analysis of the imaginary letters, the professional imagination of the future employs two main narratives, the narrative of the future of ordinary life and that of troubles. Both narratives include a variety of themes about family contact, social problems, views on the placement as well as ordinary life. The imaginary letters obviously allow social workers to verbalize some gut-feelings of the likely future of the children and parents they work with. The cheerful, friendly, pessimistic and critical letters do not come out of the blue but they inform us about the social workers' practice knowledge of children and parents during the placement and after.

This data does not allow us to explore how 'correct' the predictions of the future are and how many children, for example, would enjoy school in five years' time. We do, however, claim that the narratives are valid in the context of their writing (Riessman 2008). More important than their power to predict is how anticipation of the future directly or indirectly influences present practice. How does anticipation of a troubled future, for example, influence, restrict and unconsciously redirect practice and relationships in the present (Scanlon and Adlam 2013). Equally, why does the narrative of ordinary life especially cover those years which the child spends in care and why does the narrative of troubles become stronger when imagining the future outside the child welfare system? Supervision sessions, for example, could provide an 
important platform for critically examining the imagined futures and their relations with present practice.

The experiences with the exercise of letter writing lead us to argue that imaginary letters can be useful in social work practice and research to verbalize, and learn about, practitioners' sense of the future. Askeland (2003) argues that tacit knowledge, unconsciously integrated in mind and body without being immediately accessible for reflection, becomes visible in our actions, attitudes and prejudices, and builds a reality-play on this standpoint. Although imaginary letters, among many other such 'old-fashioned' or creative methods (Hardwick et al. 2016), could help us to learn more about gut-feeling and tacit knowledge, the key issue is not, however, to write letters from the future in a role-play model, but to use the narratives performed in the letters wisely, critically and reflectively to understand more the nuances of professional practice and knowledge.

\section{References}

Adams, R., Dominelli, L., and Payne, M., ed, 2005. Social Work Futures.

Basingstoke: Palgrave Macmillan.

Askeland, G. 2003. Reality-play - experiential learning in social work training. Social Work Education, 22 (4), 351-362.

Banks, S. 2016. Everyday ethics in professional life: social work as ethics work. Ethics and Social Welfare 10 (1), 35-52.

Barfoed, E. and Jacobsson, K. 2012. Moving from 'gut feeling' to 'pure facts': Launching the ASI interview as part of in-service training for social workers. Nordic Social Work Research 2 (1), 5-20.

Bradt, L., Roose, R., Bouverne-De Bie, M. and De Schryver, M. 2011. Data Recording and Social Work: From the Relational to the Social. British Journal of Social Work, 41 (7), 1372-1382. 
Bryant, L. ed. 2015. Critical and Creative Research Methodologies in Social Work. Burlington: Ashgate.

Chamberlayne P. and Smith M. 2007. Editorial. Journal of Social Work Practice 21, 3, 263-270.

Child Welfare Act 417/2007, unofficial translation. Retrieved from https://www.finlex.fi/fi/laki/kaannokset/2007/en20070417.pdf

Deacon, S. 2006. Creativity Within Qualitative Research on Families: New Ideas for Old Methods. In: S. Hesse-Biber and P. Leavy, ed. Emergent Methods in Social Research. London: Sage, 95-108.

Fahlgren, S. 2009. Discourse analysis of a childcare drama: Or the interfaces between paradoxical discourses of time in the context of social work. Time \& Society, 18 (2), 208-230

Featherstone, B., White, S. and Morris, K. 2014. Re-imagining Child Protection. Towards humane social work with families. Bristol: Policy Press.

Gubrium, J. and Holstein, J. 2009. Analyzing Narrative Reality. Thousand Oaks: Sage.

Hall, C. 2012. Honoring Client Perspectives Through Collaborative Practice: Shifting from Assessment to Collaborative Exploration. In: S. Witkin, ed, Social Construction and Social Work Practice. New York: Columbia University Press, 38-71.

Hardwick, L., Smith, R. and Worsley, A. 2016. Innovations in Social Work Research. London: Jessica Kingsley.

Hargreaves, R. and Hadlow, J. 1997. Role-play in social work education: Process and framework for a constructive and focused approach. Social Work Education 16, 3, $61-73$.

Healy, K. and Mulholland, J. 2010. Writing Skills for Social Workers. London: Sage. 
Hearn, J. 2012. Writing as Intimate Friends ... How Does Writing Profeminist Research Become Methodologically Challenging? In: M. Livholts, ed. Emergent Writing Methodologies in Feminist Studies. London: Routledge, 184-198.

Helavirta, S. 2016. Lapsen asioista vastaaminen huostaanoton alkuvaiheessa [Being in charge of a child in the early stages of care]. In: R. Enroos, T. Heino and T. Pösö, ed., Huostaanotto. [A Care Order]. Tampere: Vastapaino, 188-223.

Hepworth, D. and Larsen. J. 1993. Direct Social Work Practice. Pasific Grove: Brook, Cole.

Larsson, S. and Sjöblom, Y. 2010. Perspectives on narrative methods in social work research. International Journal of Social Welfare 19, 3, 272-280.

Livholts, M. ed. 2012. Emergent Writing Methodologies in Feminist Studies. London: Routledge.

Mills, C. 2000. The Sociological Imagination. Oxford: Oxford University Press.

Munro, E. 2008. Effective Child Protection. London: Sage.

Parton, N. 2008. Changes in the form of knowledge in social work: from the 'social' to the 'informational'?' The British Journal of Social Work, 38 (2), 253-269.

Parton, N. 2012. Thinking and Acting Constructively in Child Protection. In: S. Witkin, ed. Social Construction and Social Work Practice. New York: Columbia University Press, 127-153.

Pösö, T. and Huhtanen, R. 2017.Removals of children in Finland: a mix of voluntary and involuntary decisions. In K. Burns, T. Pösö and M. Skivenes, ed. Child welfare removals by the state: a cross-country analysis of decision-making systems. New York: Oxford University Press, 18-39. 
Pösö, T., Pekkarinen, E., Helavirta, S. and Laakso, R. 2016. "Voluntary" and "involuntary" child welfare: challenging the distinction. Journal of Social Work DOI: $10.1177 / 14680173166532$

Pösö, T., Helavirta, S. and Laakso, R. 2015. Time in care: the first months in care. Families, Relationships and Societies.

http://dx.doi.org/10.1332/204674315X14501122985334

Riessman, C. 2008. Narrative Methods for Human Sciences. Thousand Oaks: Sage.

Saleeby, D. 1997. The strengths perspective in social work practice. New York: Longman.

Samson, P. 2015. Practice wisdom: the art and science of social work. Journal of Social Work Practice 29, 2, 119-131.

Scanlon, C. and Adlam, J. 2013. Knowing Your Place and Minding Your Own Business: On Perverse Psychological Solutions to the Imagined Problem of Social Exclusion. Ethics and Social Welfare 7, 2, 170-183.

Seikkula, J., Arnkil, T. and Eriksson, E. 2003. Postmodern Society and Social Networks: Open and Anticipation Dialogues in Network Meetings. Family Process 42, 2, $185-203$.

Shlonsky, A. and Benbenishty, R. eds. 2014. From Evidence to Outcomes in Child Welfare. New York: Oxford University Press.

Smith, R. 2009. Doing Social Work Research. Maidenhead: Open University Press.

Swift, K.and Callahan, M. 2009. At Risk. Social Justice in Child Welfare and Other Human Services. Toronto: University of Toronto Press.

Taylor, B. 2010. Professional Decision Making in Social Work, Exeter: Learning Matters Post Qualifying Social Work Series. 
Taylor, C. and White, S. 2006. Knowledge and Reasoning in Social Work: Educating for Humane Judgement. British Journal of Social Work 36, 937-954.

Trevithick, P. 2014. Humanising managerialism: Reclaiming emotional reasoning, intuition, the relationship, and knowledge and skills in social work. Journal of Social Work Practice 28, 3, 287-311.

Ungar, M. 2004. Nurturing Hidden Resilience in Troubled Youth. Toronto: Toronto University Press.

Vehkalahti, K. 2009. Constructing Reformatory Identity: Girls' Reform School Education in Finland, 1893-1923. Bern: Peter Lang.

Warner, J. 2015. The emotional politics of social work and child protection. Bristol, UK: Policy Press.

Witkin, S. and Chambon, A. 2007. New Voices in Social Work. Writing Forms and Knowledge Production. Qualitative Social Work 6, 4, 387-395. 